\title{
Tracking Prudence: What an Iconographic Trail Reveals about Western Culture and its Pathology
}

\author{
Kathleen Warwick-Smith
}

\begin{abstract}
In the Middle Ages the cardinal virtue Prudence is revered and her depiction widespread. In the modern era, however, few Westerners esteem Prudence or can recognize her iconography. This article traces the evolution of the archetypal image of Prudence beginning in the fifth century through art and literature. By the modern era the formerly multifaceted Prudence becomes narrowly characterized as cautious or prudish, evidenced in popular culture (e.g., film). Her value might appear negligible. However, archetypal Prudence reemerges in Jung's paradigm. The lens of depth psychology further reveals the current presence of archetypal Prudence within western culture, especially its prevalent pathological presentation, which may have implications for western culture's sustainability. Prudence, as a virtue rooted in human neurobiology and the archetypal psyche, seems crucial to navigating the current manifestations of cultural and ecological chaos, perhaps demonstrating one of humanity's current psychological tasks: to bridge human consciousness with Nature.
\end{abstract}

Keywords: archetype, C. G. Jung, content analysis, iconography, James Hillman, nature, Prudence, virtue ethics

In the Middle Ages the cardinal virtue Prudence was popularly revered and her depiction widespread. However, when the topic of Prudence comes up in casual conversation, few understand prudence beyond an association with prudishness or caution. ${ }^{1}$ Fewer still can recognize her iconography. My attention was first drawn to Prudence because of her conspicuous absence in the tarot, the deck of playing cards conceived of in the Middle Ages. Since the four cardinal virtues at that time are so widely recognized with Prudence often chief among the four, her absence seemed puzzling given the presence of the other three cardinal virtues (Fortitude, Justice, and Temperance), and perhaps indicated a wider cultural development. So my inquiry broadened well beyond the medieval tarot as I gathered 574 images of artworks depicting Prudence (hereafter referred to as the archive) dating from the fifth century of the Common Era through to present day. Content analysis on 456 of those images was followed by researching Prudence's characterization in literature and to a lesser extent philosophy. ${ }^{2}$ What unfolded was a tale of how a changing culture causes Prudence - the virtue of sage and sound judgment once esteemed by Plato and Aristotle-to lose status and ultimately pass from collective sight (Warwick-Smith 66ff).

Her demotion may have implications for Western culture's sustainability. Prudence, as a virtue rooted in human neurobiology and the archetypal psyche, seems crucial to navigating the current manifestations of cultural and ecological chaos as evidenced by nuclear proliferation, biological annihilation, and global warming. Jung writes in the foreword to Depth Psychology and a New Ethic by Erich Neumann: "Nor should it be 
forgotten that moral law is not just something imposed upon man from outside (for instance, by a crabbed grandfather). On the contrary, it expresses a psychic fact. As the regulator of action, it corresponds to a preformed image, a pattern of behavior which is archetypal and deeply embedded in human nature” (15).

The virtue Prudence appears to lie within the ambit of Jung's "moral law," for virtue is the active part of ethics (moral principles) and morals (knowing right from wrong and human character). Therefore, prudence is also archetypal in the Jungian sense-an archaic pattern inhabiting the collective unconscious and manifesting as archetypal images within human consciousness. In the Middle Ages and for centuries thereafter, archetypal images of Prudence proliferate through frequent characterizations in literature and art, such as in Anticlaudianus or the Good and Perfect Man by Alan of Lille (c. 1181), Geoffrey Chaucer's The Tale of Melibee (c. 1387), and Angelica Kauffman's Beauty, Supported by Prudence, Scorns the Offering of Folly (c. 1780) to name just a few.

This article traces the evolution of the archetypal image of Prudence through art and literature and thus Western culture's relationship to that archetype, and also identifies the operation of Prudence within Jung's paradigm. Then the lens of depth psychology reveals the current presence of archetypal Prudence within Western culture, especially its prevalent pathological presentation, though Prudence is less visible now than in the last one thousand years. This unveiling reveals one of humanity's current psychological tasks: to bridge human consciousness with Nature.

\section{Introducing Prudence}

In the following pages Prudence is referred to as female following the example of the majority of artworks. Whether male or female, however, Prudence is a personification of an idea and an archetype, in this case the idea of a particular quality of virtue. In Plato's era, virtue encompasses particular skills and attitudes necessary for attaining happiness and well-being. Plato (428-348 BCE) recognizes four cardinal virtues, one of which he names Sophia or Wisdom (Protagoras 349b-c), which comprises practical wisdom, memory, and knowledge. Aristotle (384-322 BCE) contributes skill and reason to her characterization (6:1:140b). By the Roman era, the cardinal virtue Plato identifies as Sophia is more commonly called Prudentia, which the Roman philosopher Cicero (106-43 BCE) also connects to foresight (2:53). Later, Macrobius (370-430 CE) and Aquinas (1225-1274 CE) include caution and circumspection as part of prudence's extensive characterological complex (Warwick-Smith 7). Modern neuroscience continues to consider the prudential complex as including traits generally associated with Sophia and Prudentia, including deliberation, memory, goal setting, emotional regulation, reasoning, habit formation, and decision making (Larrivee and Gini 2). While ancient philosophers and modern neuroscientists generally agree on the constellation of traits comprising prudence, cultural artifacts demonstrate that archetypal Prudence's journey down through the centuries has involved more change than the consensus above would suggest.

\section{Measuring Depictions of Prudence}

Major findings from the quantitative study of the archive show that the earliest artworks of Prudence are found in Saqqara, Egypt, at the Monastery of Saint Jeremias dated to the late fifth century, and in Constantinople in the sixth century via the Anicia Julia Codex. A 
lacuna of several centuries follows until the ninth century when artworks showcasing Prudence emerge concomitantly from Germany and France. Thereafter, the primary production of artworks depicting Prudence follows the changing reign of political power: from Italy in the fourteenth century, to the Netherlands in the seventeenth century, to Great Britain in the nineteenth, and across the Atlantic to the United States in the twentieth, although the number of artworks by this time has dwindled to a trickle. Between the ninth and fifteenth centuries the majority of artworks depicting Prudence are set in a religious context; then, from the fifteenth century on, the better part of Prudence artworks present her in a secular context (lacking obvious Christian markers).

The four icons that occur most frequently in relation to Prudence are the book, serpent, mirror, and Janus face. For example, Abbot Raganaldus Blesses (Appendix A) from the ninth century shows Prudence in a religious context with the icon of the book. Alternatively, in the fifteenth century, Albrect Dürer depicts Prudence in a secular context with a Janus face while she looks into a mirror and holds a compass (Appendix A). A dragon rears at her feet. A more in-depth look at two of her emblems, the book and mirror, demonstrates how the perceived character and value of Prudence has changed over the centuries.

\section{Bookish Prudence}

Although other icons may be more frequently depicted with Prudence (i.e., the mirror and the serpent), the icon of the book has the most enduring association, stretching from the sixth century through to the early twentieth century. When the icon of the book appears in an artwork displaying Prudence, the meaning of the book might relate to any of these three streams: 1) classically connoted wisdom; 2) the Bible or Christian teachings; 3) reading, literacy, or education. The first stream of bookish Prudence is evident in Byzantium in the sixth century. Prudence is firmly established as a secular virtue linked to nobility and royalty, and allied to the classical notion of wisdom. From the archive, the depiction of Prudence from the Anicia Juliana Codex (Constantinople, c. 512 CE) (Appendix B) is the earliest extant artwork to show Prudence with a book. Prudence sits to the right of Anicia Juliana (center), a politically astute, civically minded, and wealthy citizen of Constantinople. Another virtue, Magnanimity, flanks Juliana's left. Prudence points to the red book on her lap, and a putto presents another red covered book to Juliana, which is likely the Codex (Kiilerich 177), a gift Juliana received to commemorate the restoration of a church she had funded; more books are depicted in the foreground. The composition artistically conveys Juliana's possession of the virtues of Prudence and Magnanimity while pointing to Juliana's esteem for books and education, an esteem shared throughout Byzantium in the sixth century (Baker 48).

It must be acknowledged that the symbol of the book is hardly unique to Prudence, especially in Christian iconography, even in Juliana's time. The book in association with Prudence in the Anicia Juliana Codex, though, seems to derive from the classical association of wisdom with book knowledge rather than Christian doctrine. Bente Kiilerich states that during Juliana's lifetime "the volume and later the codex had become standard attributes of wisdom (sophia) and learning" (180). This association of the book with wisdom is perhaps already centuries old. For example, at the entrance of the Celsus Library (c. 125 CE) in Ephesus, Sophia appears to hold a volume. Given the availability of classical 
texts and the cultural acceptance of artistic conventions deriving from the classical era in sixth-century Constantinople, it seems no great leap to suggest that the personifications of Magnanimity and Prudence derive from the same wellspring (Baker 50, 74-76).

The second thematic stream of bookish Prudence surfaces by the ninth century when Prudence appears in Europe refashioned for a burgeoning Christian culture saturated with Christian praxis and metaphysics. In the Anicia Juliana Codex, Prudence keeps company with only one other virtue, Magnanimity. By contrast, in the ensuing centuries, Prudence is rarely the headliner. She is more often present as one member of a virtuous crowd as shown in the "Mystic form of paradise" from the Speculum virginum where she is one of four virtues (Appendix B). In this second stream, bookish Prudence sometimes maintains a leadership role, but her stature is significantly diminished when the main characters of the Christian story take the book as part of their iconography, and the wisdom the book represents is tied to Christian teachings.

One such example is the Speculum virginum likely authored by Conrad of Hirsau (1070-1150), an educator and Benedictine monk. "Paradise" shows the evangelists, river gods, Church Fathers, Virtues, and Beatitudes circling the source, Jesus and Mary. Prudence reigns from the top left with a book in one hand and a scepter in the other indicating her standing as chief of the other virtues. At the center of the drawing, the child, Christ, sits within the embrace of the Virgin Mary. He holds a book that references the Gospel of John (7.37): "Let anyone who is thirsty come to me.” The artwork intimates that when one drinks from the waters of Paradise one imbibes the wisdom and virtue of the source. The book in Jesus's hand, inscribed with the Word of God, represents the wisdom to be consumed via reading or listening.

In the Middle Ages, when monasteries sheltered the vast majority of readers, reading is a more carnal activity of gathering spiritual food, chewing it in a slow and measured way, and then digesting it. Medievalist Ivan Illich writes that reading in the Middle Ages was a profoundly different activity than common reading practices today: "The medieval reader understands the lines by moving to their beat, remembers them by recapturing their rhythm, and thinks of them in terms of putting them into his mouth and chewing” (54). In fact monastic readers in the Middle Ages were known as mumblers and munchers. Likewise, as Morgan Powell explains in "The Speculum virginum and the Audio-Visual Poetics of Women's Religious Instruction," the Speculum virginum is intended to be read aloud by a male spiritual advisor to a group of female listeners who participate "carnally," and in Conrad's day "prudentially." Through active listening they drink from the source and take into themselves the Word through their senses in order to attain a mystical experience of the Divine (114).

The third stream of bookish Prudence relates to education when she assumes the role of mother of the Liberal Arts (the foundation of medieval education). This association probably originated with Martianus Capella’s The Marriage of Philology and Mercury (c. 410-39) where Phronesis (Prudence) and the Liberal Arts figure significantly. The Bernat van Orley Prudence tapestry (Appendix B), from the early part of the sixteenth century, shows Prudence seated upon a throne flanked by the personifications of Faith and Reason. ${ }^{3}$ The seven Liberal Arts work in the foreground constructing Prudence's chariot. In one sense the artwork communicates the idea that education drives prudent action. However, the message is deeper. The tapestry showcases a story told by Alan of Lille nearly four 
centuries earlier in his work Anticlaudianus or the Good and Perfect Man (c. 1181). The story begins as Nature realizes her own imperfection and seeks an emissary who will travel to Heaven to ask God to send a soul to earth. If God can provide a soul, then Nature can fashion a body for it, and the Virtues can help perfect it. Prudence agrees to serve as the emissary, and Wisdom enlists the Liberal Arts to construct Prudence's chariot, which will carry her to God (44-79). Reason, equipped with her trifold mirror and Prudence with a mirror gifted by Faith collaborate so that Prudence can act as mediator and bridge to facilitate the soul's descent.

The emblem of the book in association with Prudence wanes beginning in the fifteenth century. Ironically this trend is concurrent with the invention of the printing press. Illuminated manuscripts eventually give way to mass-produced books, and slow carnal reading ebbs as literacy spreads and becomes a more secular activity. The stream of bookish Prudence associated with the Liberal Arts is also impacted by cultural changes ushered in by the Renaissance. An expanded notion of education not limited to the seven Liberal Arts is instituted throughout Europe (Ross 277). Cultural change renders bookish Prudence somewhat irrelevant. However, the shift also opens the way for new interpretations, especially as in regards to another of Prudence's emblems, the mirror.

\section{Reflective Prudence}

Metal mirrors have a long history stretching back 5000 years to ancient Egypt. However, glass mirrors-albeit small and imperfect-are not manufactured in any significant quantity until after the fall of Rome. By the fifteenth century, the technique of producing crystal-clear glass is discovered, and mirrors are on their way to becoming a sought-after luxury item (Melchior-Bonnet 18). As the popularity and availability of the glass mirror rises, so does the popularity of the mirror as an emblem of Prudence until it has become her primary icon by the sixteenth century (Warwick-Smith 79). Like the emblem of the book, the mirror in association with Prudence can be divided into several streams of symbolic meaning: the mirror of self-knowledge, the mirror of reason, and the mirror of propriety.

Within the archive, the mirror first appears in an artwork by Giotto in the early fourteenth century (Appendix C) where it is likely understood as a mirror for selfknowledge. ${ }^{4}$ The mirror's connection to the self-reflective process goes as far back as Socrates who encourages his students to observe themselves in the reflection of a mirror, and to "know thyself" ("Diogenes Laertes"). This tradition continues in Christianity. Scripture is often likened to a mirror wherein one can measure and judge the state of one's soul. St. Gregory the Great (c. 540-604) writes, "The Holy Bible is like a mirror before our mind's eye. In it we see our inner face” (Discourses).

Prudence's mirror of reason, like her mirror of self-knowledge, has its origins in classical philosophy. Aristotle specifically associates reason with prudence (6:1:140b), and the association continues into the Middle Ages, the Renaissance, and through to the Enlightenment. During this time period, reason and rationality command considerable attention in philosophical treatises, theological discourses, and literary works. The mirror is often used metaphorically in these writings to represent the human mind, God's mind, or the relationship between the two. St. Anselm (1033-1109) writes, "The mind itself is the mirror and image of that Being [of God]" (Monologium LXVII). The mirror's rise in 
popularity as a household item and as an emblem of Prudence might reflect a multi-century shift towards rationalism, and the increased secular value placed on reason above emotion or faith.

Rational Prudence appears in literary works, for example, as Dame Prudence in The Tale of Melibee (c. 1400) by Chaucer who reworks an earlier tale Liber consolationis et consilii by Albertanus of Bressica (J. Powell 77), and through the character Helena in William Shakespeare's All's Well That Ends Well (1604) (Haley 11). These characters build on the motif of the prudent, well-reasoning wife working to transform her straying, ill-tempered, or impulsive husband and fall within a tradition of female prudential figures offering consolation or advice beginning with Boethius's Lady Philosophy (524-525), and continuing with Dante's Beatrice in The Divine Comedy (1308-1320), Christine de Pizan's Worldly Prudence in The Treasure of the City of Ladies, or, The book of the Three Virtues (1405), and others as noted above.

Cracks in Prudence's mirror of reason become visible, however, when the profound hardships of the medieval era cause some to question God's power of rationality. Rationality and reason, it turns out, has a slippery and unreliable nature as exemplified in Jean de Meun's The Romance of the Rose (1275) where the character named Reason plays the edge of deceit and truth (McWebb 9). ${ }^{5}$ One hundred years later, Bernat Metge pens The Book of Fortune and Prudence (1381) wherein he delivers a scathing criticism of prudence's usefulness in alleviating suffering through the character Prudence who fails the hero with her faulty reasoning. Yet, another one hundred years later in 1513 Nicolo Machiavelli (The Prince) furthers Metge and de Meun's characterizations by reducing prudence to cleverness, rationalization, persuasion, and the means towards achieving wealth and power (Garver 154). Prudence and her susceptibility to reason's lesser qualities finally finds expression in a piece by Christian Thomasius, Pietas stulta et irrationalis (c. 1723) (Appendix C). Up until this time, no other artwork in the archive depicts a vanquished Prudence.

As Western culture becomes more secularized, Prudence acquires a mirror of propriety and directs it towards social behavior. Glass mirrors find their way into more households in the eighteenth century, and the mirror for daily grooming becomes associated with beauty and sensuality. For example, in Francesco Bartolozzi's Prudence and Beauty (1782), Prudence in her Minerva-styled garb draws back scantily clad Beauty from following the flame of Love (Appendix C). A putto trails behind holding a mirror signaling perhaps that propriety has been forgotten. Another artwork by Angelica Kauffman, Beauty, Supported by Prudence, Scorns the Offering of Folly (1780) shows a similar theme. Prudence holds a mirror and helps Beauty elude the temptations of Folly. Another mirror, perhaps Vanity's, lies discarded in the foreground (Appendix C). In her new role, Prudence is less concerned with self-knowledge or reason and is instead focused on encouraging restraint and policing propriety.

Prudence's association with the mirrors of reason and propriety continues to day in popular culture, most notably in film through characters named Prudence. For example, in the 1968 British film Prudence and the Pill, Deborah Kerr and David Niven star as Prudence and Gerald, an unhappily married couple. Prudence gives Gerald the cold shoulder; Gerald, who runs a large bank in London, is equally detached. (They are each suggestive of a stereotypical split with regard to Prudence: females are prudish with sex; 
males are prudent with money.) It turns out that Prudence and Gerald are both having affairs. Four other couples fill out the cast. And, in the end each of the five woman becomes pregnant, nearly all a result of a duplicitous round-robin exchange of birth control pills that have been stolen and replaced with a placebo, then sometimes stolen and replaced again, leaving the door open for the inevitable reproductive chaos. The play on prudence and sexuality repeats forty years later in the adult film Sweet Prudence and the Erotic Adventures of Bigfoot (2011) directed by William Burke. Sweet Prudence is a Bigfoot hunter who ultimately captures, captivates, and dallies with her besotted quarry. Clearly, titillation and comedy can occur when Prudence is imprudent.

More family-friendly, Hallmark's Dear Prudence (2009) and Perfectly Prudence (2011) take up the rational Prudence theme in a two-part made-for-TV movie series. The lead character, Prudence (played by Jane Seymour), is a television show host (At Home with Prudence) who shares household hints ("Pru's Pointers") with her audience. Off the production set Prudence employs cleverness, relational adroitness, and practical knowhow to resolve difficult situations. The Dear Prudence screen writers also capitalize on the propriety theme. Prudence plays opposite Angelica, a stereotypical buxom "dumb blonde" whom Prudence eventually rescues from a relationship with a man of questionable ethics. The plot resonates with those eighteenth-century artworks that show Prudence delivering Beauty from potential sensual excess. Prudence as mistress of practicality and propriety is also developed in the character Prudence in Disney's Cinderella II (2002). Prudence is a spinster whose preoccupation with rules and precedence quashes fun and spontaneity. By the end of the movie, though, Prudence has let her hair down-literally releasing her tight bun-and dances at the ball.

From this sampling of cultural artifacts, Prudence in the twentieth- and twenty-first centuries has lost her earlier depth and is a far cry from Alan of Lille's twelfth-century heroine. Despite this turn in popular culture, the more profound conceptualizations of archetypal Prudence have arguably found expression in depth psychology, though not explicitly in name.

\section{Finding Prudence in Depth Psychology}

The language of depth psychology serves as a starting point for revealing the presence of Prudence. Phrases such as mirroring, the mirror of the unconscious, reflective listening, and seeing through invoke her iconography. Prudence and depth psychology also share the theme of the pursuit of self-knowledge. Despite these similarities, Jung rarely mentions virtue let alone Prudence in his psychological schema. When he does mention virtue, however, he calls attention to its importance to the individuation process, which

demands endless patience, perseverance, equanimity, knowledge, and ability ... on the part of the patient, the putting forth of his best powers and a capacity for suffering. . . . The deep meaning of the Christian virtues, especially the greatest among these, will become clear even to the unbeliever; for there are times when he needs them all if he is to rescue his consciousness, and his very life, from this pocket of chaos, whose final subjugation, without violence, is no ordinary task. ( $C W 16$, par. 385)

Jung points to the role the virtues play in striving for psychological healing and wholeness. 
In a footnote to the above passage, he quotes two alchemical texts, the Rosarium Philosophorum and Aurora consurgens. Both single out deliberation-a cornerstone of the prudential complex - as needed for individuation. From the Rosarium: "And you must know that this is a very long road; therefore, patience and deliberation are needed in our magistery." And from the Aurora consurgens: "Three things are necessary, namely: patience, deliberation, and skill with the instruments" (CW 16, 190, n. 43). The core nature of prudential deliberation is iconographically and symbolically denoted by Prudence's Janus face (sometimes two faces and other times three). With one eye to the past, another to the present, and still another to the future, she deliberates in order to make an informed decision in the present for the best future outcome. The Janus-face metaphor need not be time oriented. Instead with one face turned inward and another outward, Prudence holds the tension of opposing viewpoints and perspectives, such as a conscious position that stands in contradiction to an unconscious one (as perhaps revealed in a dream).

When a person relinquishes a deliberative stance and cannot hold the tension of the opposites - e.g., flies into a rage or succumbs to a sulk - the individual loses hold of the creative potential from which might arise a new symbol, perspective, sense of self, or vision of the way forward or out. As Jung states the task, "We are crucified between the opposites and delivered up to the torture until the 'reconciling third' takes shape” (375). Regulation of affect is key to reconciling the opposites, a necessary stepping stone on the path towards individuation. Deliberation takes character strength as educator Andrew Mullins writes: "Emotional regulation is at the heart of virtue because all too easily our emotional state can derail good decision making” (69). Neuroscientist, Stephen Kosslyn further elaborates: "We now know that emotion plays a major role in how we reason, and wisdom may have a lot to do with knowing when emotion is helpful and when it is not. . . People who are wise can interrupt, take a step back, and reframe” (qtd. in Hall 17).

Alan of Lille's twelfth-century heroine, Prudence, demonstrates an attitude helpful to reconciling opposites: one of humility and service. She agrees to make a perilous journey in order to benefit the greater whole: she travels to the sublime world to take delivery of a human soul and then delivers it to the substantive mundane. She is the archetypal mediatrix whose efforts result in a marriage of soul with body. Likewise, when an individual adopts such an attitude of service in the face of oppositions, transformation becomes possible. Alan of Lille's characterization of Prudence, though profound, is not the only characterization that elucidates her archetypal qualities. For example, John Ridewall (fl. 1331) also casts Prudence as mediatrix: "as a function of the Stoic World Soul” (Chance, vol. 2: 285). In addition, it may not be coincidental that Prudence becomes associated with Minerva in the Middle Ages and later with prudery or sexual abstinence, as regression of libido effectively holds the tension of the opposites. But the aspect of Prudence associated with prudery and extreme propriety seems to be a reduction worked upon her original character and demonstrates instead an aspect of her pathology.

\section{The Pathology of Prudence in the Cultural Psyche}

A concept from depth psychologist James Hillman helps reveal Prudence in the cultural psyche. In Re-Visioning Psychology Hillman observes that the psyche has a propensity to pathologize, in other words "to create illness, morbidity, disorder, abnormality, and suffering in any aspect of its behavior and to experience and image life through this 
deformed and afflicted perspective” (57). The pathology may manifest in dreams or collectively through cultural artifacts and perspectives. World War II concentration camps, for example, arose out of such an "afflicted perspective."

Hillman notes that each archetype represented by a mythological figure (e.g., Athena, Saturn, Aphrodite) has its signature pattern of pathology - a mode of behavior that appears psychologically maladaptive (Re-Visioning 79). Prudence's pathology shares common ground with Zeus's renowned daughter Athena and her Roman counterpart Minerva of whom Prudence is associated with in art. ${ }^{6}$ According to Hillman, pathological Athena defensively positions herself to parry off demands of daily living (Mythic Figures 70). By contrast, Prudence, culturally bound within the stays of a tightly drawn corset, defends against Eros. In other words, Prudence in her pathology might be impatient, cold, critical, rule-bound, or know-it-all. On the other end of the scale in her Eros-defended pathology, Prudence might lack self-knowledge or be naïve, coy, anxious, depressed, or irrational. In Bernat Metge's Fortune and Prudence (1381), Prudence's analytical nature and clear disinterest for the hero's suffering showcase another aspect of her pathology, an overidentification with reason. Metge's Prudence lacks the skill of prudential reasoning, or what neuroscience understands as the dual operation of reason and emotion.

Prudence's pathology calls for individuals to become active participants in the transformation of the Western cultural psyche. Participation means combatting the current pathological manifestations of Prudence by placing high public esteem on examples of clear rational thought over slippery reason; developing patience for the deliberative process in one's self and others while eschewing destructive, unbridled emotion; practicing foresight in one's own life and lauding public examples that, for example, put humanity's survival first over political ends or self-interest; and endeavoring to detach from insidious attitudes born from pathological Prudence such as resignation or one-sided righteousness. In short, if the Janus face of pathological Prudence were to look to the past she might recall her birthright, Wisdom.

To assuage Western culture's maladies and rekindle hope, prudential action must also skillfully engage the deeper parts of psyche-that very spring where rejuvenation resides. Not coincidentally, the discussion turns to Eros, the primordial energy that pathological Prudence defends so mightily against.

\section{Prudence and Eros}

Pathology calls out for innovative ideas, fresh images, and new stories to rejuvenate a stale perspective and transform an unrelenting cycle of personal or collective suffering. George James Cowell (1861-1916) offers one such fresh image of Prudence with his sculpture Prudence holds the Balance, but Love turns the Scale (1895), which is unique among depictions of Prudence principally because of the dynamic portrayed between Eros and Prudence (Appendix D). In the archive, Eros appears with Prudence a handful of times but is never depicted with this particular interplay. Naked and without artifice, Cowell's Prudence is far removed from the world of persona and propriety. Cowell, who exhibited at the Walker Art Gallery, the New Gallery, and the Royal Academy between 1886 and 1914, was part of the British New Sculpture movement known for mythological subject matters portrayed through dynamic naturalism-a counter-response to the rigid neoclassicism that predominated earlier in the century. 
Prudence looks at the scale in the same manner as she might look into a mirror. In fact, the pans of the scale-resembling metal mirrors of old - might be interpreted as mirrors reflecting back two manifestations of psyche-consciousness and the unconscious. Prudence considers both, holding the tension of the opposites in delicate balance. The scale also signifies deliberation, and her attention to the scale suggests an intuitive awareness of the animating force behind its movement and life itself, namely Eros.

In Cowell's work Eros delights in tipping the scales to instigate a relationship of endless surprise. Prudence, for her part, pays rapt attention to changing circumstance. In many ways the theme resonates with a problem that Hillman addresses: "The question remains: can the arbitrary spontaneity of . . . Lady Fortuna [or Eros] . . . be managed by any strategy at all?" He asks the question within a discussion regarding Athena and concludes that "strategy offers no protection to surprise” (Mythic Figures 78). Athena's forward thinking cannot take into account every eventuality. Likewise, as Metge observes in the fourteenth century, virtue offers no assurances against life's calamities (31). However, Prudence's skill with deliberation, mediation, and holding tension seems well suited to handling the "surprising forces of unpredictable events" (Hillman, Mythic Figures 79).

Cowell's depiction of Prudence suggests an interiority and an engagement with Nature. It is difficult to discern from the photo available of Cowell's work whether Prudence sits upon a stone, tree stump, or patch of earth. Whatever the case may be, the symbolism of Eros's emergence from the substance upon which Prudence sits is intriguing. Perhaps the artistic convention of Prudence above Eros conveys her triumph over love while also intimating that Prudence and Eros are but two sides of one coin. Whether the symbolism is intended by Cowell or not, the sculpture metaphorically encapsulates the idea of Eros in matter, and the need for a prudential relationship to both. From The Wisdom of the Ancients (1609), Francis Bacon in a chapter entitled "Cupid or the Atom” offers an interpretation of "Love" that resonates:

They say then that Love was the most ancient of all the gods; the most ancient therefore of all things whatever, except Chaos, which is said to have been coeval with him . . . This Love I understand to be the appetite or instinct of primal matter; or to speak more plainly, the natural motion of the atom; which is indeed the original and unique force that constitutes and fashions all things out of matter. (839-40)

Cowell's work prefigures an emergent perspective of a living universe receptive to dialogue and relationship through a mediating imaginal and coincides with the dawn of modern depth psychology.

In Cowell's work, the mediating third is the scale, which allows for communication between Prudence and Eros. Freya Mathews, an Australian philosopher, reinvigorates the argument for a panpsychic view of Nature. In For Love of Matter: A Contemporary Panpsychism, she argues for a renewed communicative relationship with the world around us. It is beyond the scope of this article to differentiate between her philosophy, Jung's notions of the anima mundi and the lumen naturae, Hillman's idea of the anima mundi as that "seminal image which offers itself through each thing in its visible form" (Thought of the Heart 101), and other conceptualizations of an ensouled world. However, what these notions generally hold in common is some semblance of the metaphoric third or a mediating phenomenon. Mathews suggests language, especially song and poetry, can serve 
as mediums of communication (9, 81). Jeffrey Miller suggests an imaginal "field" as the metaphoric third as a way of opening liminal space for communication to flow between Nature and individuals, or between individuals themselves (139).

During the early centuries of the Christian era, Prudence is dismissed from Wisdom's heights and relegated to practical matters. Though Alan of Lille bequeaths Prudence the gift of navigating the supernal realm, Earth does seem her rightful home. Here she can, for example, attend the laundry as in the penultimate alchemical image in the sequence of the alchemical Splendor Solis, sort grain like Psyche, sweep cinders like Cinderella, or attend to shoelaces as Roberts Avens advises: "we begin by paying attention to shoelaces and forget . . . about the Shoemaker" (129). If we join forces with Prudence, our noses point to the earth and do not rise in disdain of it. Matter matters. No one knows that better than Prudence when she volunteers to help Nature in her plight and ultimately brings soul back to the world and to humanity. To this end Jungian-oriented therapists and Jungian-minded individuals are well placed to employ a mediating third to converse with Nature and engage the imagination to bring forth much-needed new perspectives and fresh stories for Western culture.

Cowell's depiction of Prudence and Eros speaks to humanity's present task to invite, entertain, and understand Nature and the psyche in a bimodal manner-narratively and scientifically, inclusive of the nonrational and the rational-that resonates with Timotheus Vermeulen and Robin van den Akker's metamodernism, which they coin as an "emergent neoromantic sensibility" ("Notes"). The metamodern perspective "believes in one system or structure or sensibility, but also cannot persuade itself not to believe in its opposite ("What Meta Means"), a perspective suited to prudence. So, in the spirit of the metamodern and turning from the nonrational, neurobiology offers something to this discussion.

\section{Depth Psychology, Virtue Ethics, and the Neurobiology of Prudence}

In my professional practice, my clients' ethical impulses are of concern, because when clients strengthen and exercise virtue (especially the Platonic four) they tend to heal and become happier. However, only a few Jungian-oriented commentators, such as Erich Neumann and Murray Stein, have considered the intersection of depth psychology and ethics. Stein addresses the topic in a chapter entitled "The Problem of Ethics" in Minding the Self: Jungian Meditations on Contemporary Spirituality. He examines whether the inner-focused individuation process, upon which the psychology of Jung centers, works against ethical concerns that are relational, societal, and communal instead of individual. Stein argues that the individuation process, though person-focused in nature, benefits society: "the individual . . . has the capacity to affect society and the physical world (for good or ill) because the individual, society, and the natural world are intimately connected parts of a single reality" (93). In other words, the effect of individuation goes beyond setting a good example for others to follow; its reverberation is widespread.

Stein notes the importance of an ethical attitude that "requires a person deeply to care for other people, the community and the natural world" (92). But he does not query how depth psychology is or is not conducive towards generating such an ethical attitude, beyond fostering individuation. He may stop short in order to follow Jung's example. Jung saw blanket moral precepts as inadequate, especially from a psychological standpoint: "The analyst learns that ethical problems are always intensely individual ... the collective rules 
of conduct offer at most provisional solutions" (13). He makes this statement in a foreword (1949) to Erich Neumann's Depth Psychology and a New Ethic wherein he also observes that neurosis most often results because of "conflicts of conscience and difficult moral problems" (11). He admits that he has sought to avoid the discussion of morals because morality belongs to the field of philosophy and not psychology. However, he recognizes that the field of ethics needs to be reconsidered in light of an unconscious that holds its own moral standpoint, thus rendering ethics a psychological concern (18). Depth psychologists in the twenty-first century might benefit by intentionally recognizing "virtue ethics" (concerning character development, not social code) as essential to its paradigm and native to the habitat of psyche.

Martin Seligman, researcher, founder of Positive Psychology, and co-author together with Christopher Peterson of Character Strengths and Virtues (2004), has made an extensive cross-cultural study of virtue. From his results Seligman hypothesizes a universal evolutionary predisposition:

These particular styles of behaving may have emerged, been selected for, and been sustained because each allows a crucial survival problem to be solved. Without biologically predisposed mechanisms that allowed our ancestors to generate, recognize, and celebrate corrective virtues, their social groups would have died out . . . the ubiquitous virtues, we believe, are what allow the human animal to struggle against and to triumph over what is darkest within us. (52)

Seligman is not alone in this assessment. Some neuroscientists are concluding that psyche is not a tabula rasa (Goodwyn 18).

Recent research in the field of neuroscience has focused on prudence and related areas. Interestingly, some researchers revert to the systems of Plato, Aristotle, and Aquinas to organize their inquiries into virtue. For example, neuroscience researchers Denis Larrivee and Adriana Gini write:

Aquinas' insistence on rational deliberation as the necessary, conscious precursor . . . to virtuous behavior, is receiving renewed neuroscientific interest . . . Moreover, the reflective process of deliberation is a manifestly and universal social tool ... [T] he practical reasoning spoken of by Aquinas, and by which prudence must be exercised, is very much in its infancy from the vantage of a neuroscientific understanding. (2)

Neurobiological findings about the operation of prudence within the human brain suggest that the prudential complex is innate (2), which makes sense given the dualistic nature of human perception. Nature may have equipped humans with a tool-i.e., the prudential complex - to handle such oppositions. Without the benefits of current neurobiological research, Jung observes the innate compensatory operation of the psyche through the toand-fro dialogue of consciousness and the unconscious. This compensatory characteristic might also fall under the prudential umbrella-a type of autonomic prudence, selfregulating and operating without conscious will.

Psyche in the compensatory functioning of its parts-consciousness and the unconsciousness, is itself prudent and deliberative. In fact, it might be more accurate instead to conceive compensation, which Jung posits as a mechanistic response that exerts 
an opposing force-as part of an unconscious problem-solving process that seeks resolution and is deliberative in nature. This reformulation takes the conception of the psyche one step away from a modern mechanistic presumption and one step towards a more spirited notion of the human psychological process; i.e., the psyche is prudent rather than compensatory. Mullins states that "good habits [are] the neural bases of character" (69). In other words, repetitive use of the neural networks associated with an identified virtuous behavior increases the strength of those networks, making the behavior easier to do and repeat: "Indeed, all behaviors for which there is a demonstrable need for repeated or habitual performance are likely to be undergirded by such plastic mechanisms, including the execution of virtue” (Larrivee and Gini 2). Thus, therapists might endeavor to strengthen their clients' prudential neural networks by encouraging them to deliberate (perhaps reframing indecision as the process of deliberation), or to form habits such as dreamwork and journaling, habits that are among the mainstays of depth work.

One thing seems clear so far from this brief exploration at the intersection of prudence, neuroscience, and depth psychology: prudence pervades the psyche from its deepest unconscious layers to its most superficial conscious ones, from human biology to an individual's psychology, and seems key not only to humanity's survival but also for the flourishing of culture. Prudence is indispensable and ubiquitous.

\section{Conclusion}

Humanity must experience a rebirth of prudential values to survive, for Nature needs humanity's responsible presence immediately. Alan of Lille's Prudence came to the aid of Nature at Her behest. Nature's call is being heard once more from Nature herself and through her emissaries on the airwaves (songs about healing the planet have been playing since the 1960s) and on the internet (e.g., "2020: Race to Save the Planet," on The Weather Channel). One especially clear prudential voice stands out, internationally recognized, environmental activist, sixteen year-old Greta Thunberg who states, "We can't just continue living as if there was no tomorrow, because there is a tomorrow" (qtd. in Alter). One only hopes that it is not too late to heed these calls. Perhaps it is no mistake that the modern definition of prudence has been reduced to caution. Wittgenstein views language as a "cage" (qtd. in Tarnas 399). Even if the modern narrow definition of prudence limits the modern individual's ability to be prudent in the fuller sense understood by those living in bygone eras, the current global predicament is so fraught with converging risks that the human race could do worse than proceed with due caution.

Individuals across time have woven a collective tapestry of Prudence that demonstrates how a culture takes hold of new images and releases others in a constant flow of creative expression crafted by consciousness and the unconscious, individual psyches, and the collective psyche. As Jungian analyst Stein writes: "There are no accidents in the meandering and vicissitudes of historical process. It is going somewhere, producing a specific image that needs to be mirrored and reflected in human consciousness" (216). Prudence's story is a woven pattern, though, which is tentative, evolving, and incomplete. Prudence remains emergent as befits an archetypal energy that continues to work among us, through us, and within us. 


\section{Contributor}

Kate Warwick-Smith, Ph.D. (Mythological Studies, Pacific Graduate Institute), M.A. (Counseling Psychology, California Institute for Integral Studies) resides in Sonoma, California and works as a Licensed Marriage and Family Therapist in private practice. She is also the author of the Tarot Court Cards: Archetypal Patterns of Relationship in the Minor Arcana (Inner Traditions, 2003).

\section{Notes}

${ }^{1}$ I capitalize Prudence when speaking of the cardinal virtue, the archetype, and characters named Prudence; I use a lower case prudence when referring to prudence as a quality of virtue, an idea, or common trait.

${ }^{2}$ Content analysis is a "counts and amounts" social science research approach. In practice, coders examine a message set (a large body of data consisting of texts, images, films, or audio recordings), evaluate each message of the set based on predetermined variables, and then record their observations. The results are tabulated, and statistical analysis is applied to determine what might be significant. In my study of Prudence, the message units were artworks depicting Prudence.

${ }^{3}$ In the Honors tapestry Prudence does not carry a book but holds a serpent, another of her emblems. Still, her depiction here seems aligned with the stream of bookish Prudence, for education and the Liberal Arts are predominantly "liber centric."

${ }^{4}$ Further research may yield earlier artworks featuring Prudence with a mirror, given that Alan of Lille's Anticlaudianus places a mirror in Prudence's hands some two hundred years earlier.

${ }^{5}$ In the thirteenth century Jean de Meun elaborates upon a work begun by Guillaume de Lorris and turns a story of courtly love into a racy allegory of sexual conquest. He employs a personification named Reason who plays the edge of deceit and truth.In the Middle Ages, Athena's Roman counterpart Minerva is often connected to Prudence, evidenced by Prudence's occasional usurpation of the goddess's shield and helmet. The affiliation is no doubt influenced by the Vatican Mythographers, the Second of whom writes, "He killed Medusa with the help of Minerva because virtue overcomes all fears with wisdom as its helper. Moreover, Minerva is imagined to have Medusa's head on her breast because all prudence is in that place, and prudence confounds others and shows them to be "stony" and ignorant” (Pepin 154). Indeed, some illustrations show Prudence with Medusa upon her breast.

\section{Works Cited}

“2020: Race to Save the Planet.” The Weather Channel, 7 Nov. 2019.

Alan of Lille, and James J. Sheridan. Anticlaudianus or The Good and Perfect Man. Pontifical Institute of Mediaeval Studies, 1973.

Alighieri, Dante. The Divine Comedy. Translated by Allen Mandelbaum and Peter Armour, Knopf, 1995.

Alter, Charlotte, et al. "Time 2019 Person of the Year-Greta Thunberg." Time, www.time.com/person-of-the-year-2019-greta-thunberg/. Accessed 16 Feb. 2020.

Anselm. Basic Writings. Translated by S. N. Deane, Open Court, 1994. 
Aristotle. Aristotle's Nicomachean Ethics. Translated by Joe Sachs, Focus, 2002.

Avens, Roberts. The New Gnosis: Heidegger, Hillman, and Angels. Spring Publications, 1984.

Bacon, Francis. The Wisdom of the Ancients. 1609. The Philosophical Works of Francis Bacon: Reprinted from the Texts and Translations with the Notes and Prefaces of Ellis and Spedding. Routledge, 1905.

Baker, Katherine M. The Anicia Juliana Codex: A Product of Cultural Inheritance and Appropriation in 6th-Century Byzantium. 2013. University of Oklahoma. Master's thesis.

Capella, Martianus. The Marriage of Philology and Mercury. Columbia UP, 1977.

Chance, Jane. Medieval Mythography. Vol. 2, UP of Florida, 1994-2015. 3 vols.

Chaucer, Geoffrey. “The Tale of Melibee: A Modern English Translation.” The Geoffrey Chaucer Page, The President and Fellows of Harvard College, www.sites.fas.harvard.edu/ chaucer/teachslf/mel-tran.htm. Accessed 20 Feb. 2020.

Cicero, Marcus Tullius. Treatise on Rhetorical Invention and Treatise on Topics. Translated by C. D. Yonge, Digireads Publishing, 2010.

Cinderella II: Dreams Come True. Directed by John Kafka, Walt Disney Pictures, 2001.

Conrad of Hirsau. "Speculum virginum: Selected Excerpts.” Translated by Barbara Newman. Listen Daughter the Speculum Virginum and the Formation of Religious Women in the Middle Ages. Edited by Constant J. Mews, Palgrave, 2001, pp. 269-296.

Coogan, Michael D., et al., editors. The New Oxford Annotated Bible with Apocrypha: New Revised Standard Version. Rev. 4th ed., Oxford UP, 2010.

Dear Prudence. Directed by Paul Schneider, Hallmark Channel, 2009.

“Diogenes Laertius: Stoic Doctrines (1).” www.attalus.org/old/diogenes7b.html\#92. N.p., n.d. Accessed 30 Jan. 2017.

Elder, George R. The Snake and the Rope. Dog Ear Publishing, 2012.

Garver, Eugene. Machiavelli and the History of Prudence. U of Wisconsin P, 1987.

Goodwyn, Erik D. The Neurobiology of the Gods: How Brain Physiology Shapes the Recurrent Imagery of Myth and Dreams. Routledge, 2012.

Gregory the Great. Discourses. www.tertullian.org. Accessed 5 May 2017.

Haley, David. Shakespeare's Courtly Mirror: Reflexivity and Prudence in All's Well That Ends Well. U of Delaware P, 1993.

Hall, Stephen S. Wisdom: From Philosophy to Neuroscience. Alfred A. Knopf, 2010. Hillman, James. Mythic Figures. Spring Publications, 2007.

—. Re-Visioning Psychology. Harper Perennial, 1975.

- The Thought of the Heart and the Soul of the World. Spring Publications, 1992.

Illich, Ivan. In the Vineyard of the Text: A Commentary to Hugh's Didascalicon. U of Chicago P, 1993. 
Jung, C. G. The Collected Works of C. G. Jung. General Editor, Sir Herbert Read et al., translated by R. F. C. Hull, 2nd. ed., Princeton UP, 1953-79. 20 vols. Bollingen Series 16.

— Foreword. Depth Psychology and a New Ethic, by Erich Neumann. Shambhala, 1990, pp. 11-18.

— Letters. Edited by Gerhard Adler and Aniela Jaffé, translated by R. F. C. Hull, vol. 1, Princeton UP, 1973. Bollingen Series 95.

Kiilerich, Bente. “The Image of Anicia Juliana in the Vienna Dioscurides: Flattery or Appropriation of Imperial Imagery?” Symbolae Osloenses, vol. 76, no. 1, 2001, pp. 169-190.

Larrivee, Denis, and Adriana Gini. "Is the philosophical construct of 'habitus operativus bonus’ compatible with the modern neuroscience concept of human flourishing through neuroplasticity? A consideration of prudence as a multidimensional regulator of virtue.” Frontiers in Human Neuroscience 18 Sept. 2014, www.ncbi.nlm.nih.gov/pmc/articles/PMC4166998/. Accessed 19 June 2017.

Lorris, Guillaume de, and Jean de Meun. The Romance of the Rose. Translated by Harry W. Robbins, E. P. Dutton, 1962.

Machiavelli, Nicolo. The Prince. 1513. Translated by N. H. Thompson, Value Classic Reprints, 2017.

Mathews, Freya. For Love of Matter: A Contemporary Panpsychism. State U of New York P, 2003.

McWebb, Christine. "Hermeneutics of Irony: Lady Reason and the Romance of the Rose.” Dalhousie French Studies, vol. 69, 2004, pp. 3-13.

Melchior-Bonnet, Sabine. The Mirror: A History. Routledge, 2001.

Metge, Bernat. The Book of Fortune and Prudence. Translated by David Barnett, John Benjamins Publishing Company, 2013.

Miller, Jeffrey C. The Transcendent Function: Jung's Model of Psychological Growth through Dialogue with the Unconscious. State U of New York P, 2004.

Mullins, Andrew. “The neuroscience of character development.” Independence, vol. 40, no. 1, May 2015, pp. 68-72.

Neumann, Erich. Depth Psychology and a New Ethic. Shambhala, 1990.

Pepin, Ronald E. The Vatican Mythographers. Fordham UP, 2008.

Perfectly Prudence. Directed by Paul Schneider, Hallmark Channel, 2011.

Pizan, Christine de, and Sarah Lawson. The Treasure of the City of Ladies, or, The book of the Three Virtues. Penguin Books, 2003.

Plato. The Collected Dialogues of Plato, Including the Letters. Edited by Edith Hamilton and Huntington Cairns, Pantheon Books, 1961.

Powell, James M. Albertanus of Brescia: The Pursuit of Happiness in the Early Thirteenth Century. U of Pennsylvania P, 1992.

Powell, Morgan. "The Speculum virginum and the Audio-Visual Poetics of Women's Religious Instruction.” Listen Daughter: The Speculum Virginum and the 
Formation of Religious Women in the Middle Ages, edited by Constant J. Mews, Palgrave, 2001, pp. 111-135.

Prudence and the Pill. Directed by Fielder Cook and Ronald Neame. Twentieth CenturyFox Productions, 1968.

Quibell, J. E. Excavations at Saqqara, 1907-1908. Le Gaire Imprimerie de l'Institut Français d’Archeologie Orientale, 1909.

Ross, Leslie. Medieval Art: A Topical Dictionary. Greenwood Press, 1996.

Seligman, Martin E., and Christopher Peterson. Character Strengths and Virtues: A Handbook and Classification. Oxford UP, 2004.

Shakespeare, William. All's Well That Ends Well. The Complete Words of Shakespeare. Edited by Peter Alexander, Collins, 1951, pp. 316-348.

Stein, Murray. Minding the Self: Jungian Meditations on Contemporary Spirituality. Routledge, 2014.

Sweet Prudence and the Erotic Adventure of Bigfoot. Directed by William Burke, Epona Films, 2012.

Tarnas, Richard. The Passion of the Western Mind: Understanding the Ideas That Have Shaped Our World View. Ballantine Books, 2011.

Vermeulen, Timotheus, and Robin van den Akker. "Notes on Metamodernism.” Journal of Aesthetics and Culture, vol. 2, no.1, 2010, www.tandfonline.com/doi/full/10.3402/jac.v2i0.5677. Accessed 22 Nov. 2014.

_. "What Meta Means and Does Not Mean." Notes on Metamodernism, www.metamodernism.com/2010/10/14/what-meta-means-and-does-not-mean/. Accessed 29 Nov. 2014.

Warwick-Smith, Kathleen. Remembering Prudence: Tracking the Iconography of a Cardinal Virtue to Her Resurgence in Depth Psychology. 2017. Pacifica Graduate Institute. PhD dissertation. Proquest. 


\section{Appendix A}
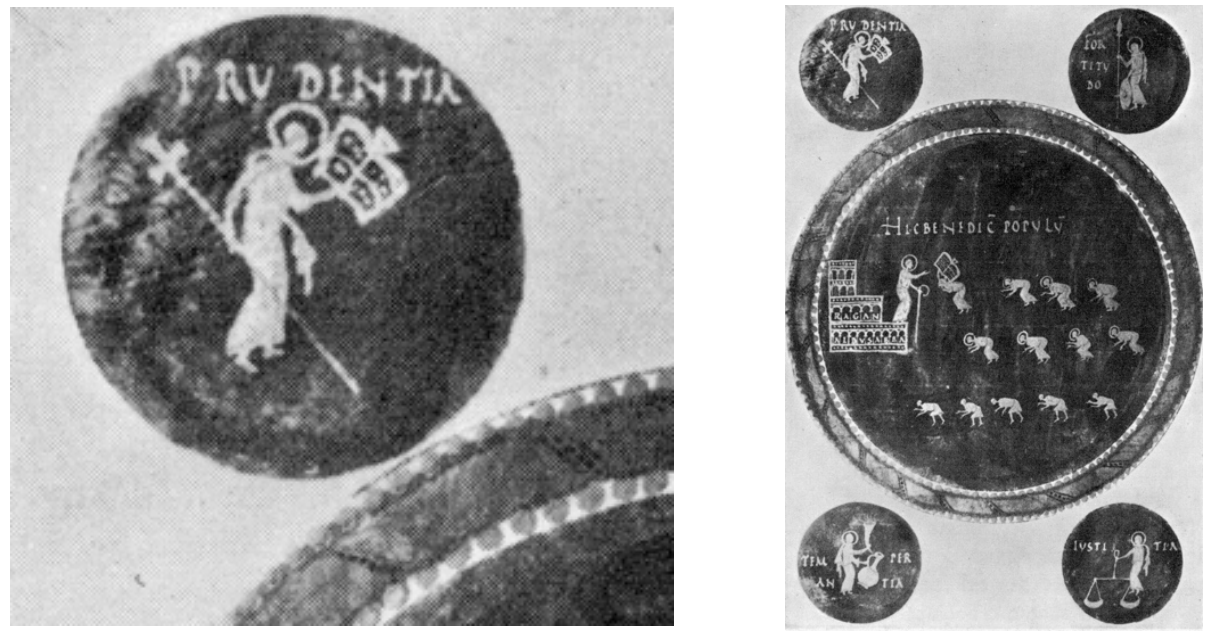

Abbot Raganaldus Blesses, Autun Sacramentory, c. 850, France. Prudence with scepter and book resides at the top left of the artwork (close up on left). The other three cardinal virtues-Fortitude, Justice, and Temperance-are depicted clockwise from Prudence. Source: reprinted with permission by ARAS Online, file 5Ck.064.

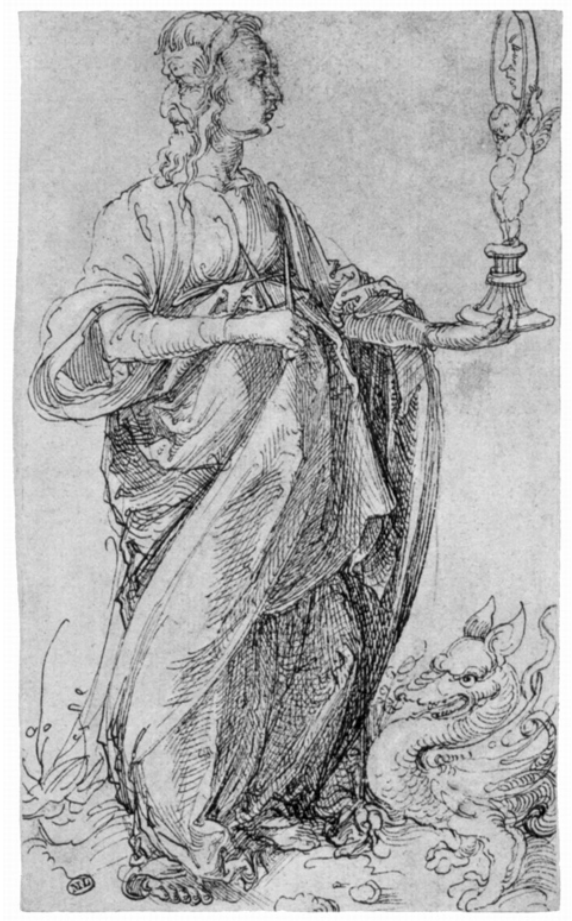

La Prudence, Albrecht Dürer, c. 1494. Source: Wikiart, public domain. 


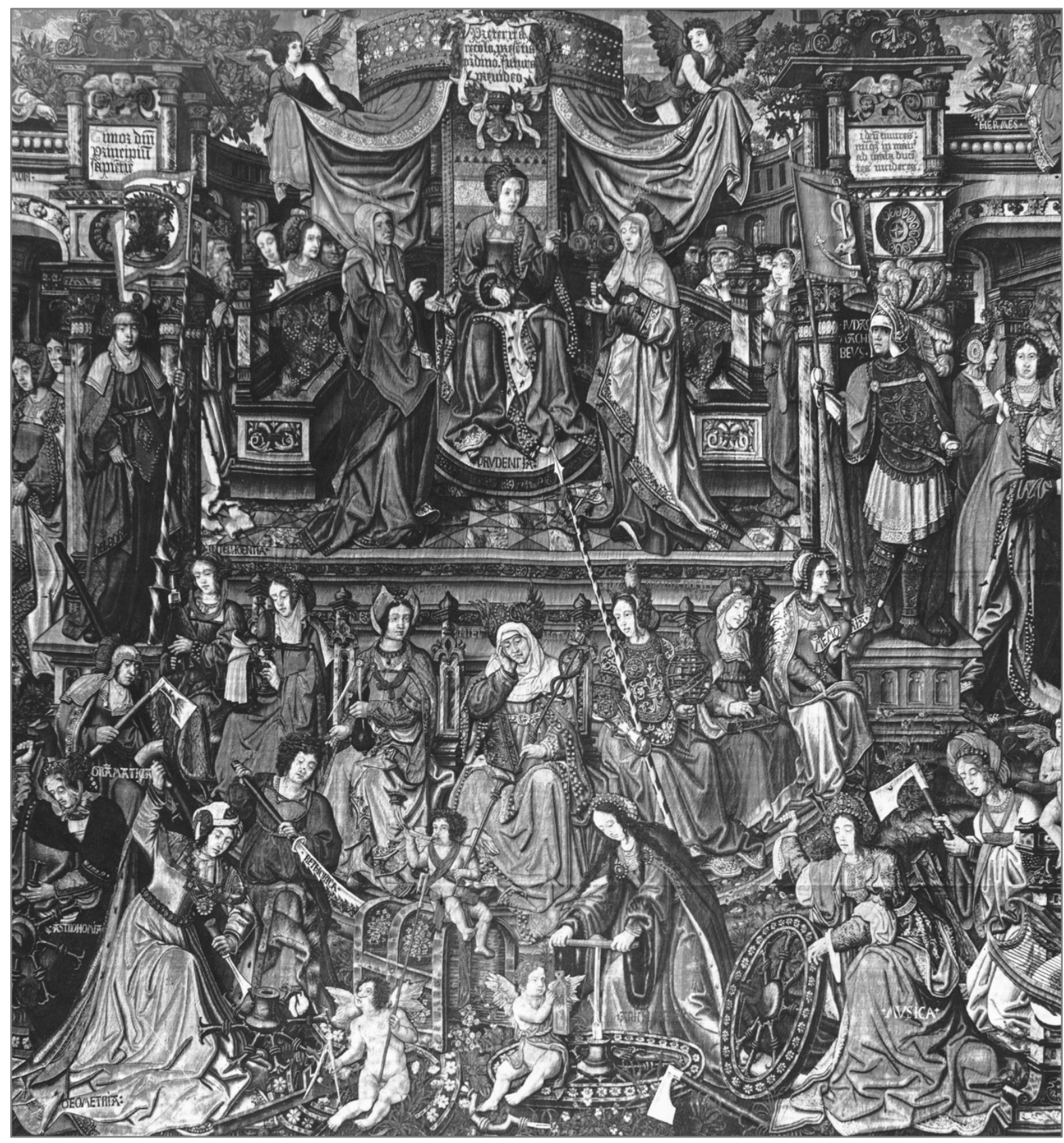

Prudence, Bernart van Orley tapestry, c. 1520-23. Source: Digital images courtesy of the Getty’s Open Content Program, public domain. 


\section{Appendix B}

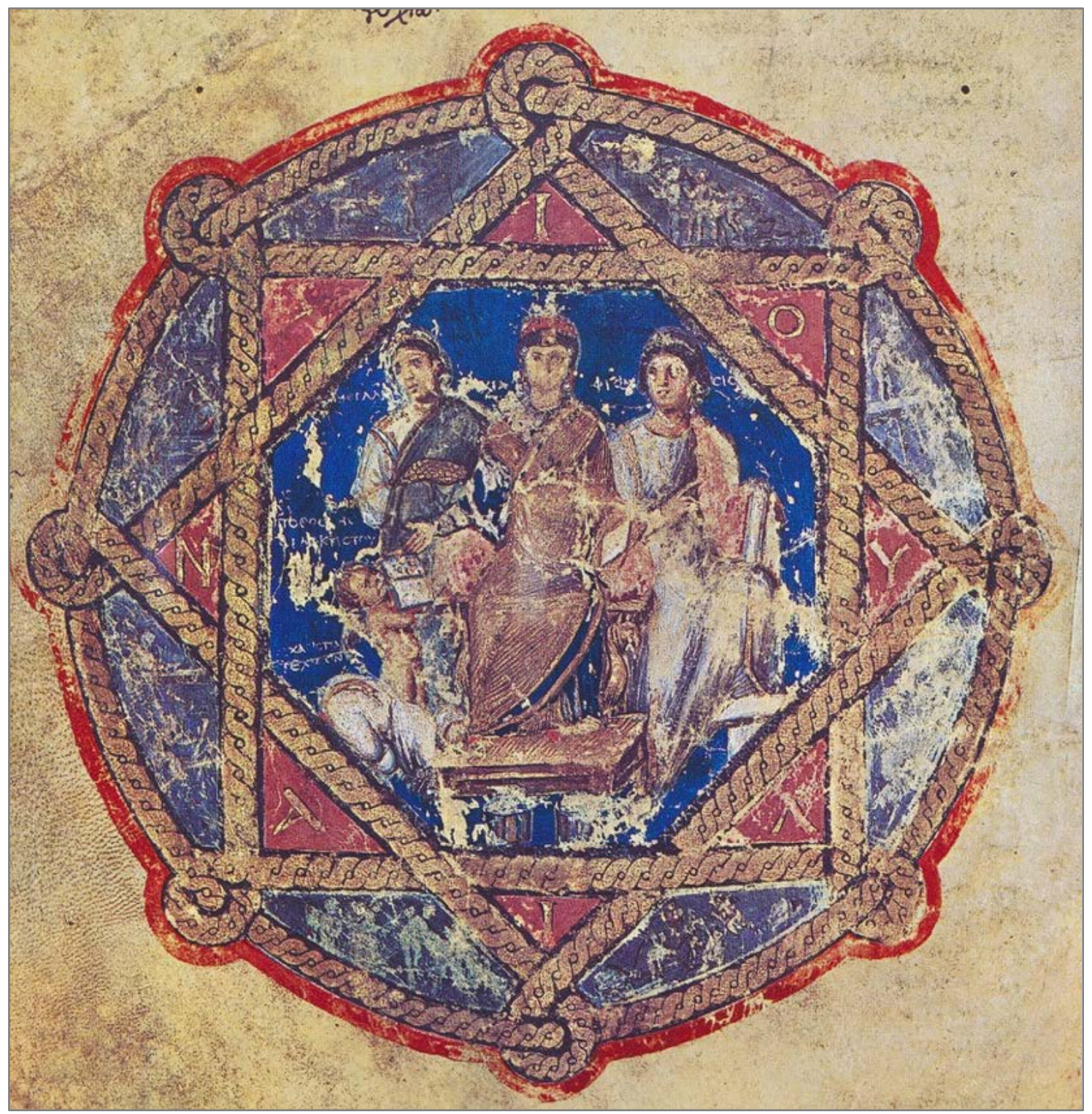

Dedication folio (fol. 6), Anicia Juliana Codex, 512 CE, Constantinople. Source: Dioscorides: Codex Vindobonensis medicus Graecus 1 of the Austrian National Library, public domain. 

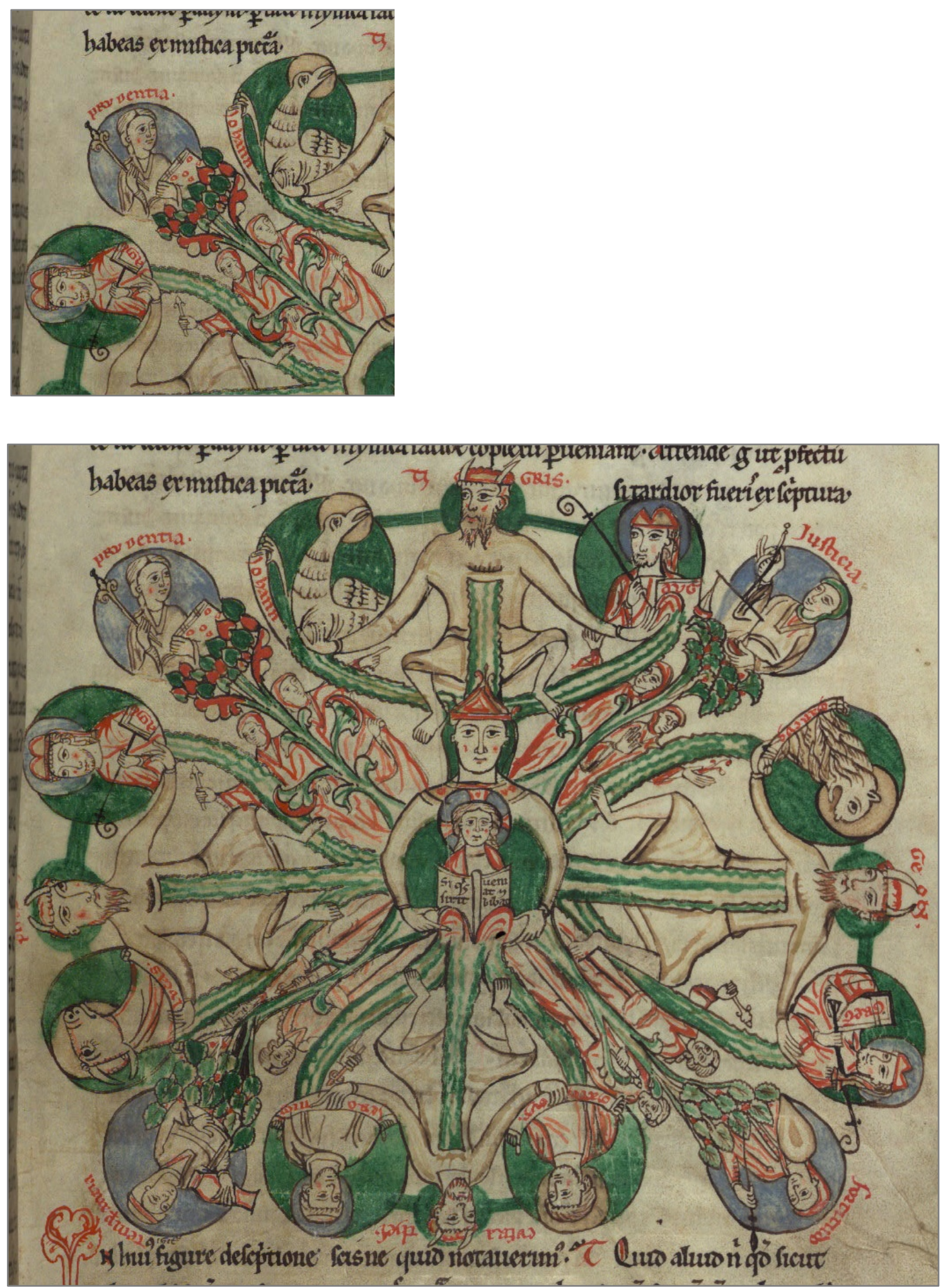

Mystic form of paradise, Speculum virginum c. 1225 Chapter 1, thirteenth folio. Prudentia in top left. Source: The Walters Art Museum, Digitized Walters Manuscripts, public domain. 


\section{Appendix C}

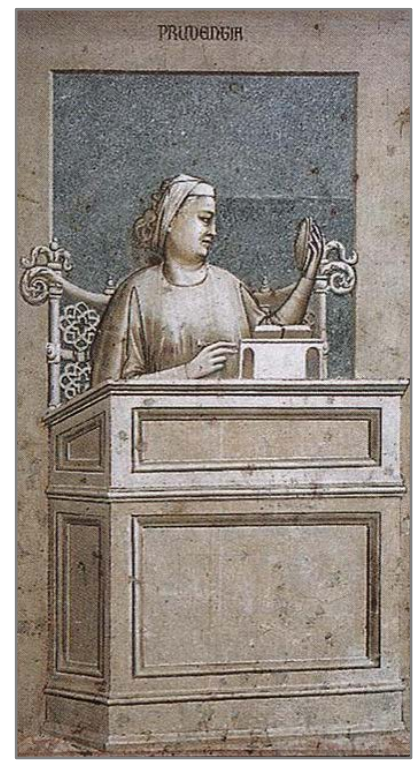

Prudence, Giotto, Arena Chapel, c. 1303. Janus-faced Prudence stands at a lectern in front of an open book and looks into a mirror. Source: reprinted with permission by Artstor Digital Library.

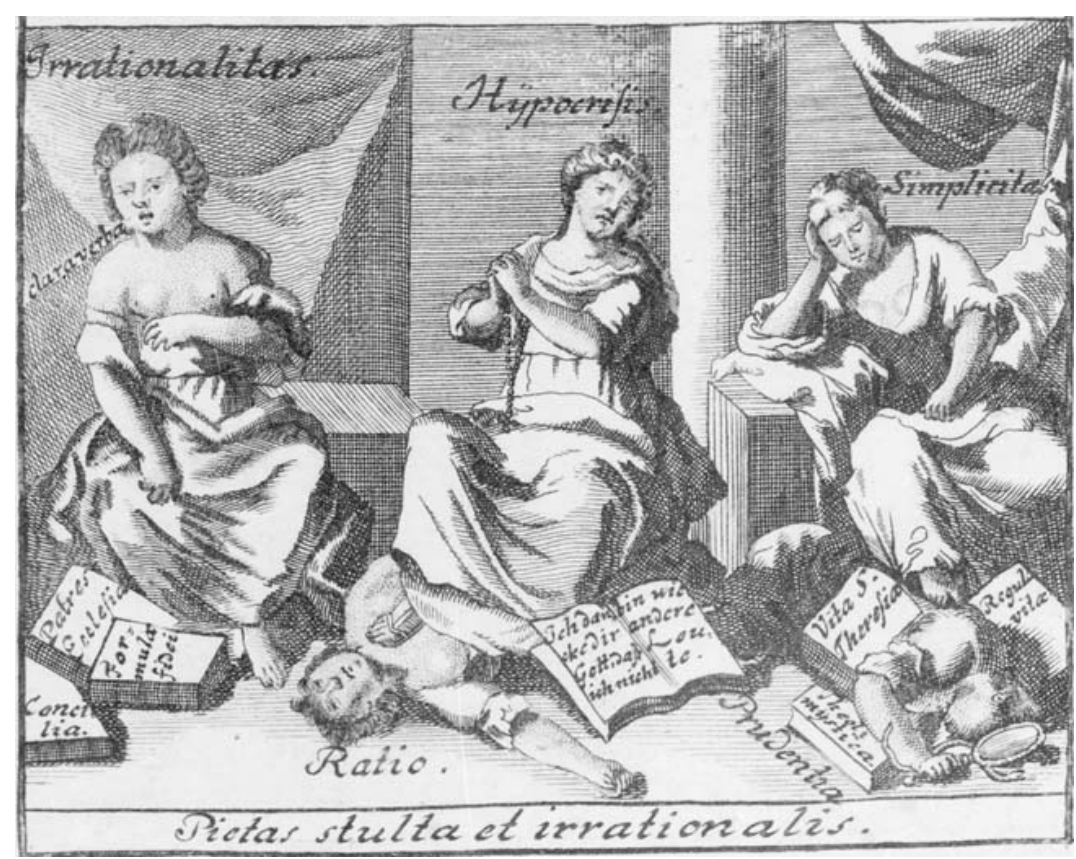

Pietas stulta et irrationalis, Christian Thomasius, c. 1723. Reason and Prudence are defeated by Irrationality, Hypocrisy, and Simplicity. Source: Martin-Luther-Universität Halle-Wittenberg, public domain. 


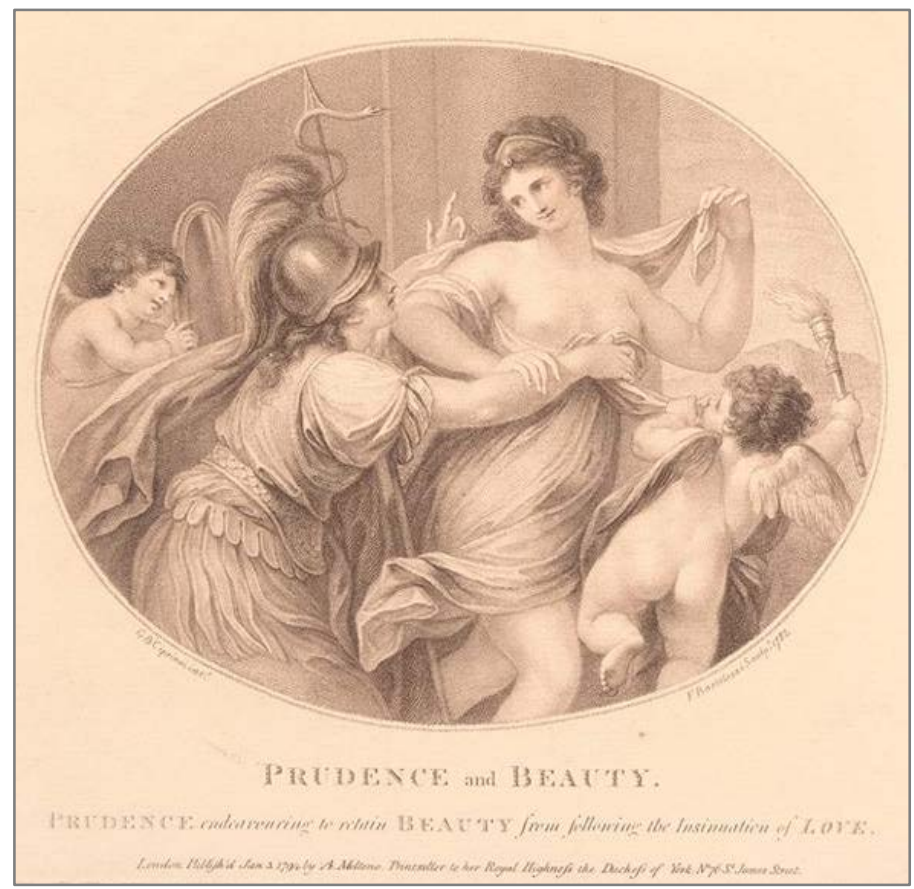

Prudence and Beauty, Francesco Bartolozzi, c. 1782, Great Britain. Source: reprinted with permission, (C) Trustees of the British Museum.

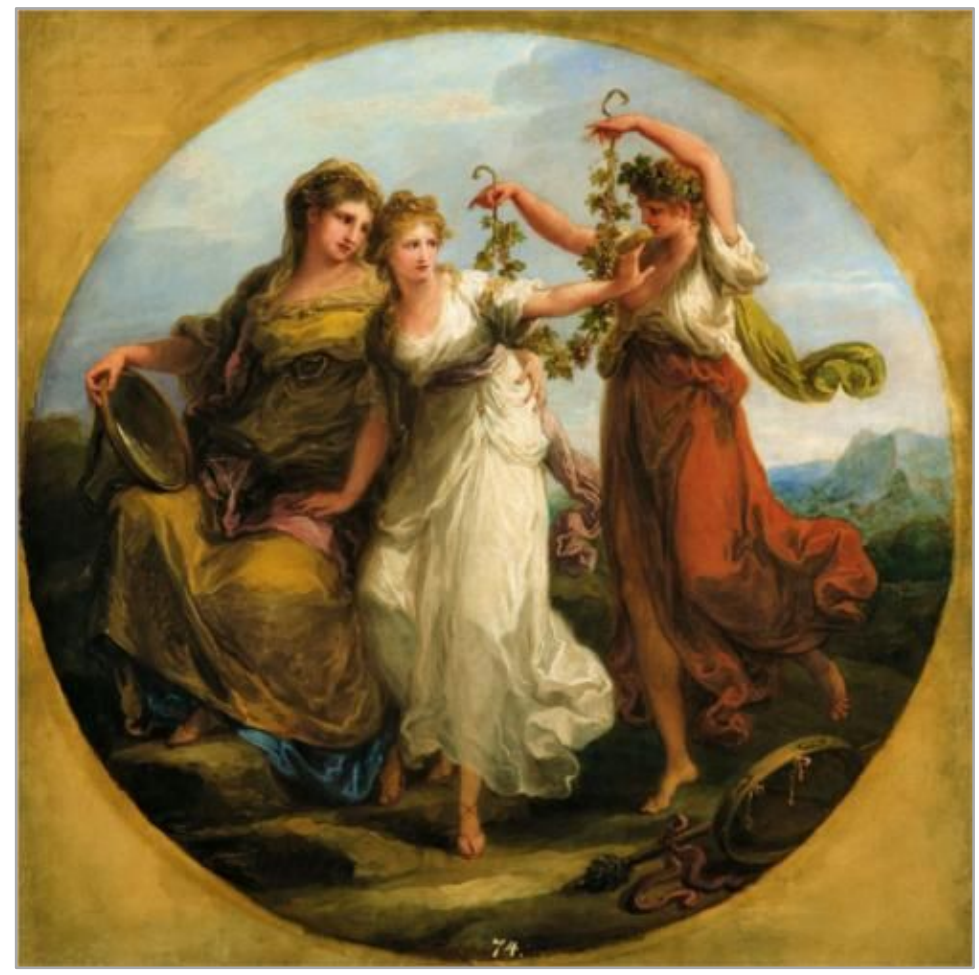

Beauty, Supported by Prudence, Scorns the Offering of Folly, Angelica Kauffman, c. 1780, Great Britain. Source: Wikimedia Commons, public domain. 


\section{Appendix D}

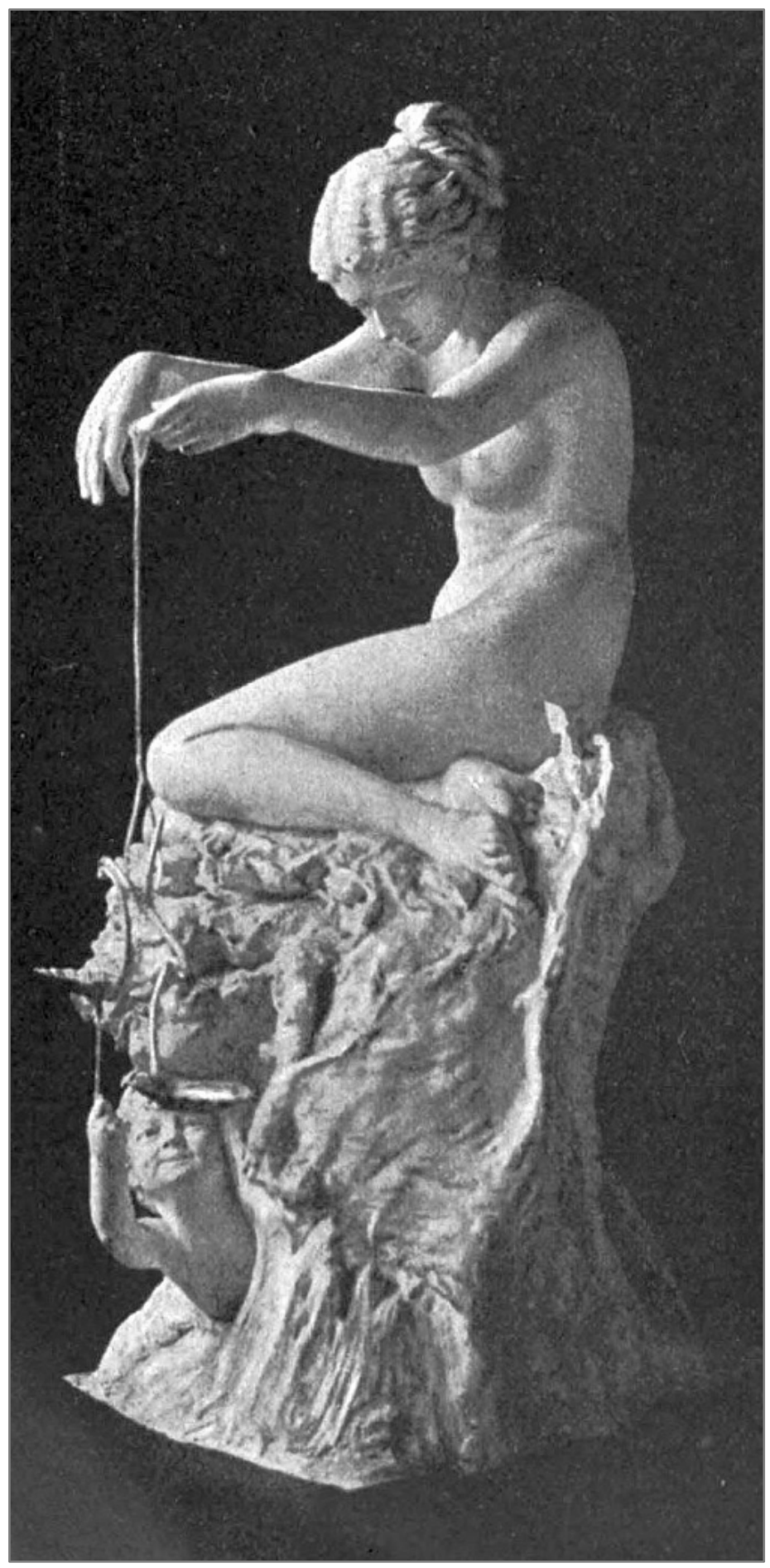

Prudence holds the Balance, but Love turns the Scale, sculpture by George Covell [sic], late nineteenth century, Great Britain. Source: Academy Architecture and Architectural Review, 1895, vol. 8, public domain. 